\title{
Analisis Video Likes to Viewers Ratio Youtube Pada 5 Kosmetik Terbaik Di Dunia
}

\author{
Nur Haliza Lukman \\ Halizaalizaa475@gmail.com
}

\begin{abstract}
Information and communication technology is currently developing rapidly, this has made more and more types of social media applications appear with different features and functions. One of the most frequently used and influential social media applications is YouTube. This research was conducted with the aim of finding the ratios contained in the YouTube account. These ratios will later be used to measure the performance of an account mathematically. This research was conducted using an exploratory method to find the variables contained in the YouTube account. These variables will be compared and juxtaposed to test their relevance so that they become the relevant ratios. The relevant ratio will be used to assess the performance of each account on YouTube social media. The results of this YouTube social media research show that there are 6 variables, these variables are posts, subscribers, likes, dislikes, viewers, comments. The six variables will be compared and juxtaposed to find 10 relevant ratios. The benefit that can be taken from this research is that in the future it can easily assess, measure and compare the credibility of each YouTube account using the 10 ratios that have been found.
\end{abstract}

keywords : credibility youtube account ; social media ; social media account; youtube channel ; youtube ratios.

\begin{abstract}
Abstrak
Teknologi informasi dan komunikasi saat ini telah berkembang dengan pesat, hal ini membuat semakin banyak jenis aplikasi sosial media yang muncul dengan fitur dan fungsi yang berbedabeda. Salah satu aplikasi sosial media yang sering digunakan dan memiliki pengaruh besar adalah YouTube. Penelitian ini dilakukan dengan tujuan untuk menemukan rasio-rasio yang terdapat pada akun YouTube. Rasio-rasio ini yang nantinya akan digunakan untuk mengukur performa sebuah akun secara matematis. Penelitian ini dilakukan dengan menggunakan metode ekploratif untuk menemukan variabel-variabel yang terdapat pada akun YouTube. Variabel tersebut yang nantinya akan dibandingkan dan disandingkan untuk diuji relevansinya sehingga menjadi rasio yang relevan. Rasio yang relevan akan digunakan untuk menilai performa setiap akun yang ada pada sosial media YouTube. Hasil dari penelitian sosial media youtube ini menunjukan bahwa terdapat 6 variabel, variabel tersebut diantaranya yaitu post, subscriber, likes, dislikes, viewers, comments. Keenam variabel tersebut yang nantinya akan dibandingkan dan disandingkan sehingga menemukan 10 rasio yang relevan. Manfaat yang dapat diambil dari penelitian ini yaitu kedepannya dapat menilai, mengukur serta membandingkan kredebilitas dari setiap akun youtube dengan mudah menggunakan 10 rasio yang telah ditemukan.
\end{abstract}




\section{PENDAhuluan}

Teknologi informasi dan komunikasi yang telah berkembang dengan pesat mampu menghantarkan manusia untuk menciptakan bentuk baru dalam cara berkomunikasi serta berinteraksi melalui media sosial. Media sosial memberikan pengaruh yang cukup besar, saat ini media sosial diajadikan sarana berkomunikasi dalam setiap aktifitas keseharian bersosial di masyarakat. Komunikasi tidak hanya dapat dilakukan secara fisik, tetapi juga dapat dilakukan dengan menggunakan berbagai aplikasi media sosial di dunia maya. Keunggulan layanan aplikasi sosial media adalah memberikan ruang komunikasi dua arah antara konsumen-perusahaan dan konsumen-konsumen.

Dengan pesatnya perkembangan teknologi media sosial, telah memberikan dampak terhadap situssitus komunikasi, dari yang awalnya hanya sekedar email dan chatting, saat ini sudah banyak jejaring media sosial yang bisa digunakan sebagai alat komunikasi. Contoh aplikasi sosial media yang memiliki banyak pengguna saat ini yaitu YouTube. YouTube merupakan sebuah platform untuk mempublikasikan video, platform ini resmi berdiri pada tahun 2005. Pendirinya adalah Chad Hurley, Steve Chen, Jawed Karim dimana mereka bertiga adalah mantan karyawan PayPal. Kemudian platform YouTube dibeli oleh Google dan diperkenalkan Kembali pada tahun 2006. (Maulida, 2017)

Di Indonesia, terdapat 170 juta pengguna YouTube yang aktif menggunakan media sosial di Indonesia. Maraknya jumlah pengguna YouTube aktif di Indonesia tentu dapat memberikan peluang bagi brand untuk menjadikan platform ini sebagai platform social media marketing. Cukup banyak akun perushaan-perusahaan terkenal yang ada pada YouTube, contohnya seperti vendor Kosmetik di Indonesia. Adapun Top 5 Vendor Kosmetik di Indonesia, diantaranya yaitu : Estee Lauder, Revlon, Maybelline New York, MAC Cosmetics, Lancome "5 Kosmetik terbaik di dunia menurut salah satu situs internet"(BPguide, 2018)

Penelitian ini dilakukan dengan menggunakan metode ekploratif untuk menemukan variabelvariabel yang terdapat pada akun YouTube.Variabel tersebut yang nantinya akan dibandingkan dan disandingkan untuk diuji relevansinya sehingga menjadi rasio yang relevan. Rasio yang relevan akan digunakan untuk menilai performa setiap akun yang ada pada sosial media YouTube. Hasil dari penelitian sosial media youtube ini menunjukan bahwa terdapat 6 variabel. Keenam variabel tersebut yang nantinya akan dibandingkan dan disandingkan sehingga menemukan 10 rasio yang relevan.(Hendika Permana, 2021) 



\section{TINJAUAN PUSTAKA}

Perkembangan bidang teknologi saat ini terjadi begitu pesat. Melalui perkembangan yang terjadi dari waktu ke waktu menimbulkan maraknya aplikasi - aplikasi serta platform media sosial yang bermunculan. Aplikasi yang sangat diminati oleh masyarakat saat ini diantaranya adalah YouTube, TikTok, Instagram, Twitter, WhatsApp dan yang lain sebagainya. Seiring berjalannya waktu, aplikasi sosial media tersebut dapat menjadi candu bagi kalangan masyarakat. Tidak hanya kalangan remaja yang menggunakan aplikasi sosial media, orang tua bahkan anak-anak juga aktif menggunakan aplikasi sosial media tersebut.

Youtube Merupakan salah satu aplikasi media yang paling popular di Indonesia, hal ini menunjukkan bahwa Youtube menjadi aplikasi yang paling banyak digemari. Penggunaan internet di Indonesia sangat aktif menggunakan Youtube. Youtube merupakan jejaring sosial media berbentuk video dan tidak ada maximal durasi. Layanan yang paling sering digunakan sehingga mencapai angka pengguna yang fantastis merupakan layanan streaming video dan music. (Fachruddin, Sutiyana. Jaya, 2020).

Salah satu ciri khas sosial media Youtube adalah dapat mengetahui video pengguna atau content creator yang cukup sering di tayangkan sehingga video tersebut menjadi popular dan masuk ke dalam video Trending topic.

Youtube salah satu layanan dari Google yang memfasilitasi pengguna untuk meng-upload dan bisa diakses oleh pengguna yang lain dari seluruh dunia secara gratis. Youtube adalah sebuah situs web video sharing (berbagi video) popular dimana para pengguna dapat memuat, menonton, dan berbagi klip video secara gratis. Umumnya video-video di Youtube adalah klip music (video klip), film, TV, serta pembuatan para pengguna nya sendiri. Pengguna dapat menjadi content creator dan pengguna dapat menghasilkan uang melalui konten yang diunggahnya di Youtube.(Literate \& Indonesia, 2020).

Aplikasi Youtube tidak hanya digunakan untuk membuat konten video untuk tujuan menghibur pengguna lainnya saja. Youtube juga dapat dijadikan peluang bagi brand atau perusahaan sebagai platform social media marketing (Soelistyowati, 2018) menyatakan bahwa Youtube merupakan media promosi digital yang fleksibel. Selain dapat mempromosikan sistem jasa terbaru mereka,pihak perusahaan juga dapat melihat testimonia tau komentar, kritik dan saran yang dibuat para warganett sebagai "bahan koreksi" mereka dalam meningkatkan mutu dan pelayanan jasa yang diberikan oleh perusahaan ini kepada konsumennya. 



\section{METODE PENELITIAN}

Penelitian ini menggunakan metode eksploratif kuantitatif untuk mengetahui kredibilitas dari performa akun Youtube 5 vendor Kosmetik terbaik di Dunia. Metode eksploratif merupakan penelitian yang memiliki tujuan untuk melakukan eksplorasi atau memperdalam pengetahuan ataupun ide-ide baru mengenai suatu hal yang baru, guna merumuskan permasalahan secara terperinci.(Maryam, 2016)

Tujuan dari penelitian ini yaitu mengetahui nilaii kredibilitas dari performa akun Youtube 5 Kosmetik Terbaik di Dunia. Ada beberapa Langkah yang harus dilakukan dalam penelitian ini, sehingga mampu menemukan peringkat pertama dari akun Youtube Kosmetik Tebaik di Dunia yang memiliki performa terbaik. Langkah-langkah yang di lakukan pada penelitian ini diantara nya yaitu :

\section{1) Menentukan Esplorasi Pada Website Untuk Menentukan Obbjek Yang Akan Dianalisa.}

Eksplorasi ini dilakukan pada beberapa halaman website yang menyediakan informasi mengenai objek yang akan di teliti. Setelah eksplorasi selesai, sehingga ditemukan namanama Kosmetik Terbaik Di Dunia yang akan dijadikan objek analisa. Setelah melakukan eksplorasi pada halaman website, maka langkah selanjutnya yaitu mencari nama akun Youtube dari masing-masing Kosmetik Terbaik Di Dunia. Pastikan semua Kosmetik memiliki akun pada aplikasi sosial media Youtube.

\section{2) Menghitung Nilai Rata-Rata Variable Dari 5 Kosmetik Terbaik Dunia}

Pada langkah ini, peneliti menghitung nilai variable likes dan viewers . Variabel merupakan sesuatu yang memiliki nilai bervariasi dimana nilai tersebut dapat dijadikan sebagai dasar untuk empat data yang berbeda seperti rasio, skala, ordinal, nominal dan internal (Hendika Permana, 2021). Untuk menghitung nilai rata-rata dari variabel video comments dan variabel video likess yaitu dengan cara mengambil 5 postingan kemudian di hitung sehingga menemukan nilai rata-rata dari masing-masing variabel.

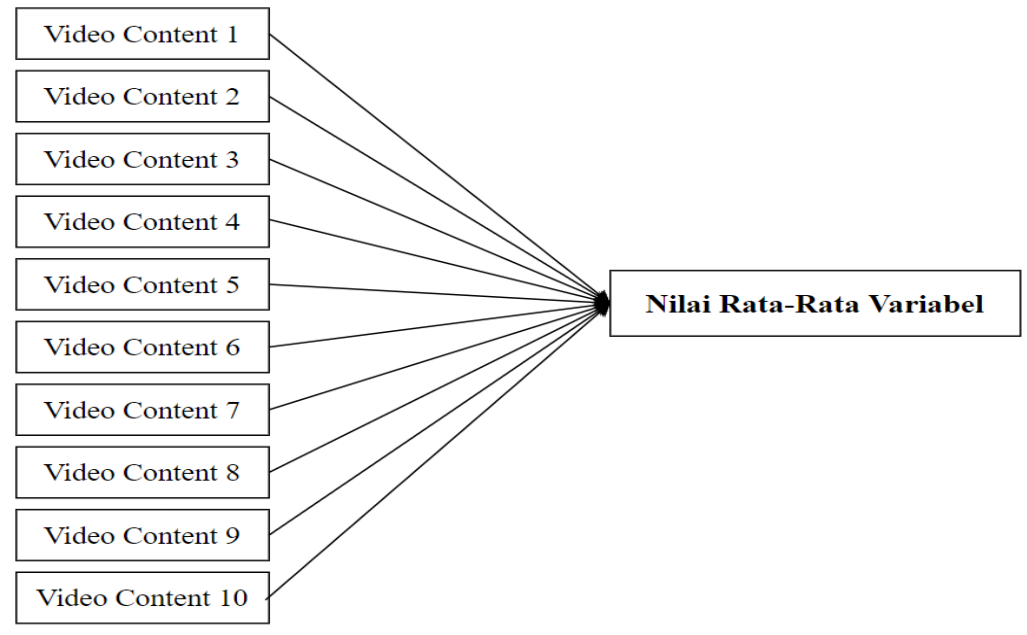

Gambar 1. Analisa Nilai Rata-Rata Variabel 


\section{3) Menghitung Nilai Kredibilitas Rasio}

Untuk menghitung nilai kredibilitas dari likes to viewers ratio, peneliti menggunakan cara membagi nilai variabel pertama dengan nilai variabel kedua. Jika video comments memiliki nilai 200 dan video likes memiliki nilai 400, maka cara menghitungnya yaitu 200 : $400=0,5$. Dengan begitu nilai dari video comments to video views ratio adalah 0,5 .

\section{4) Menentukan Peringkat Pada Akun Youtube}

pada langkah terakhir yaitu menentukan peringkat pada masing-masing rasio yang ada. pada penentuan peringkat perlu melihat karakteristik dari rasio yang di teliti. Bila karakteristik rasio ialah rendah, maka objek yang memiliki nilai terendah akan mendapatkan angka 5 serta objek yang memiliki nilai tertinggi akan mendapatkan angka 1. tetapi Bila rasio memiliki karakteritik tinggi maka objek yang menerima nilai tinggi akan mendapatkan angka 5 serta objek yg menerima nilai terendah akan mendapatkan angka 1. setelah mendapatkan hasil kredibilitas ratio maka dapat disimpulkan objek yang mana mendapatkan peringkat 1 sampai dengan peringkat 5 . 


\section{HASIL DAN PEMBAHASAN}

Akun Youtube dari 5 Kosmetik Terbaik di Dunia, diantaranya:

\section{Estee Lauder}

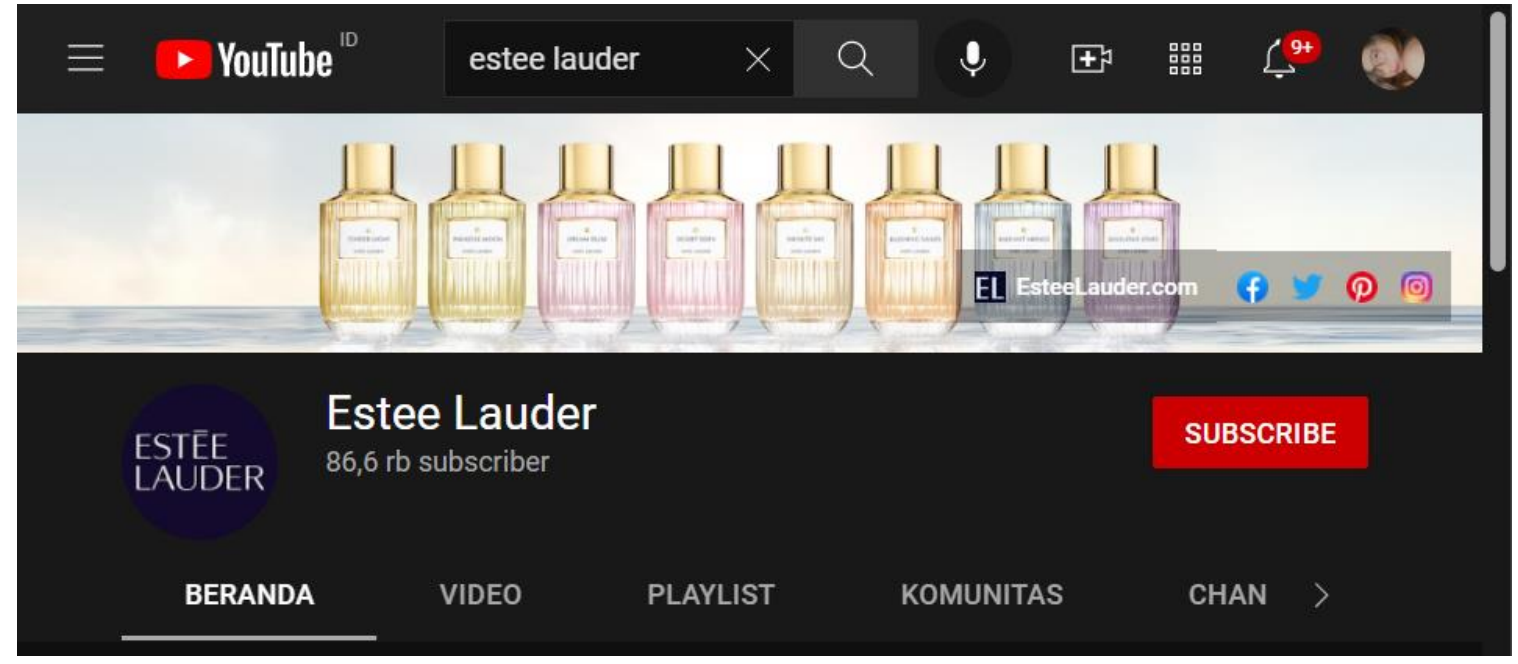

Gambar 1 Akun Youtube Estee Lauder

Sumber: https://www.youtube.com/c/EsteeLauderEL/featured

(diakses pada 21-10-2021)

\section{Revlon}

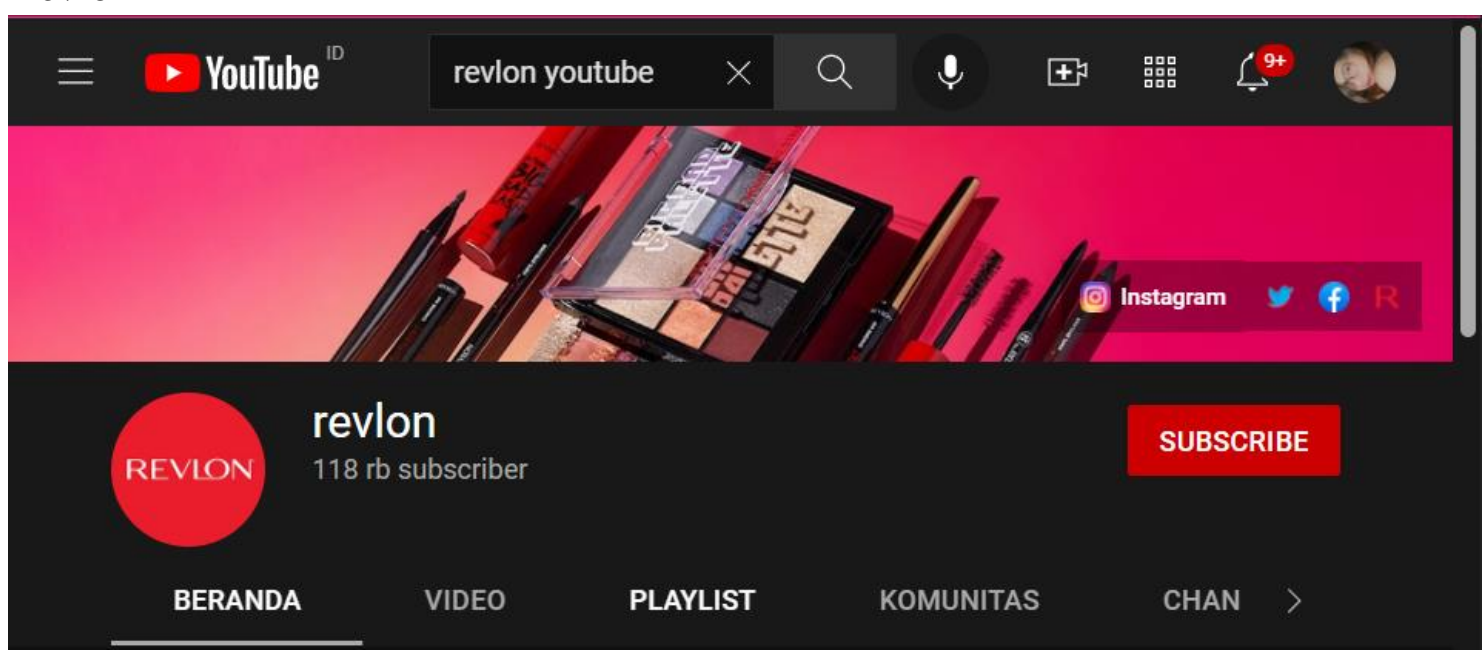

Gambar 2 Akun Youtube revlon

Sumber: https://www.youtube.com/user/revlon

(diakses pada 21-10-2021) 
3. Maybelline New York

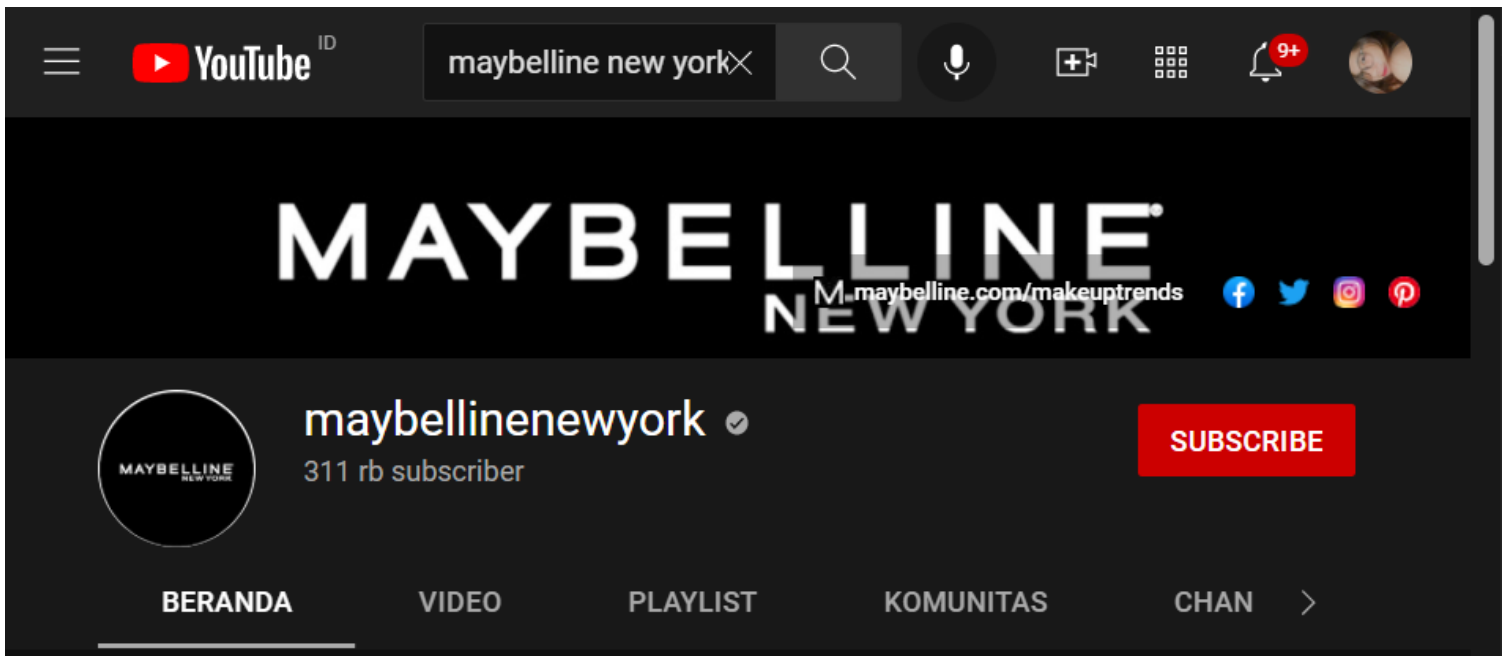

Gambar 3 Akun Youtube Maybelline New York

Sumber: https://www.youtube.com/user/maybellinenewyork

(diakses pada 21-10-2021)

\section{MAC Cosmetics}

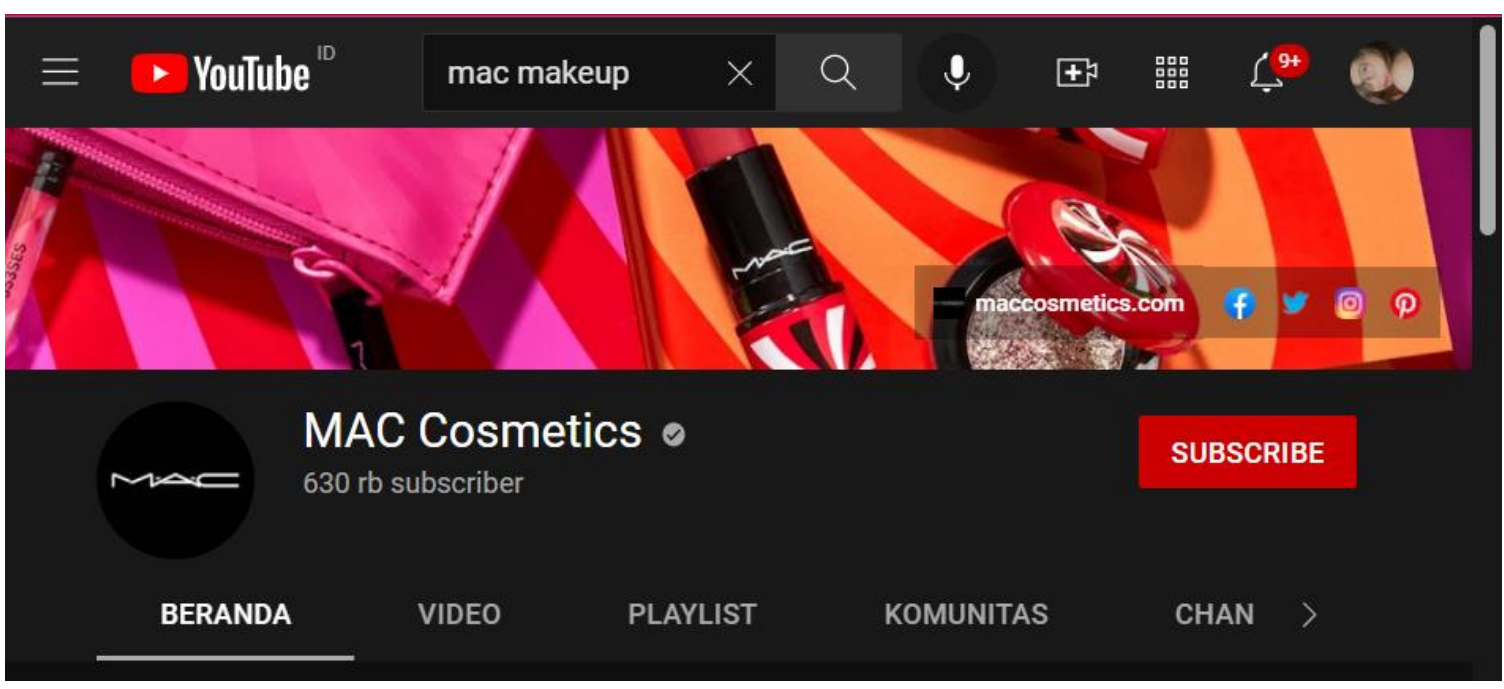

Gambar 4 Akun Youtube Mac Cosmetics

Sumber: https://www.youtube.com/user/MACcosmetics

(diakses pada 21-10-2021) 


\section{Lancome}

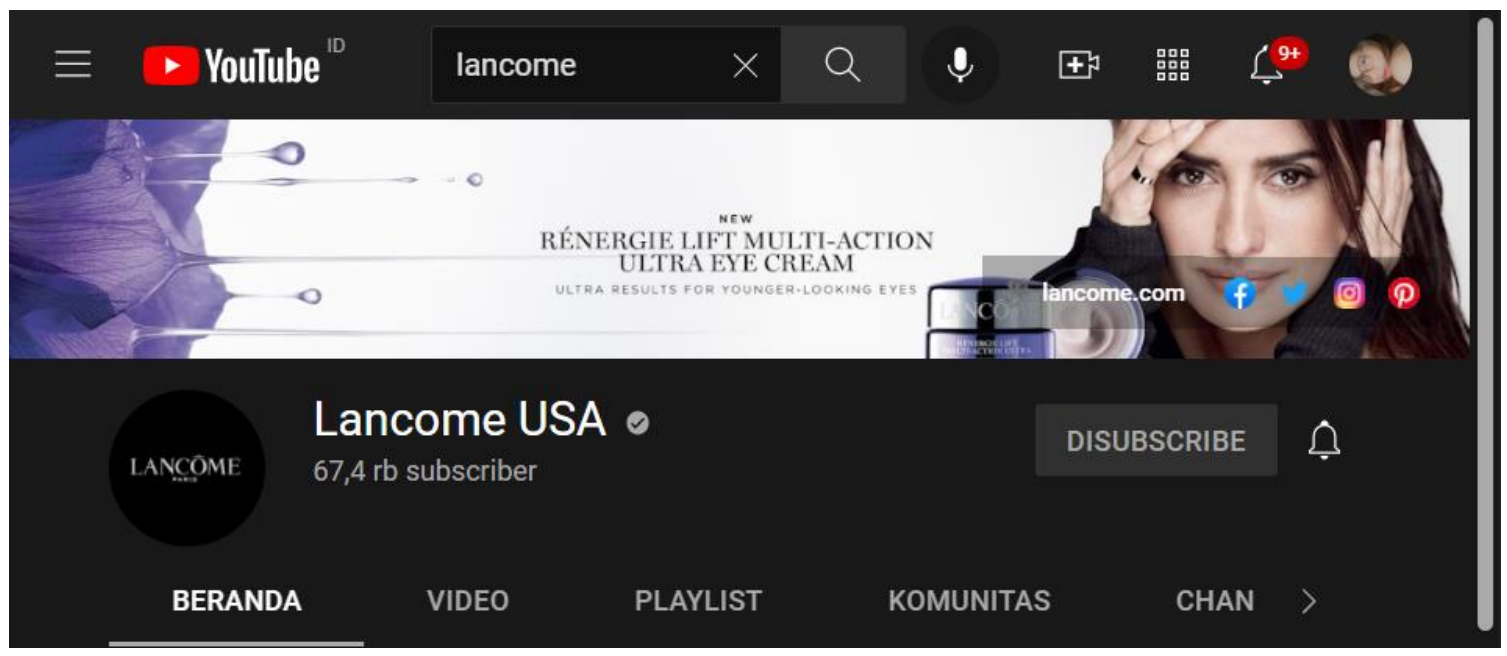

Gambar 5 Akun Youtube Lancome

Sumber: https://www.youtube.com/user/LancomeStudio

(diakses pada 21-10-2021)

Dari lima akun Youtube 5 Kosmetik Terbaik Didunia, peneliti menemukan nilai dari masingmasing variable yang ada untuk menghitung rasio Video Likes to Reviews dari setiap akun diatas. Pada akun Youtube memiliki enam variabel, diantaranya yaitu:

1. Post

2. Subscriber

3. Likes

4. Dislikes

5. Viewers

6. Comments

Dari keenam variable tersebut peneliti hanya focus untuk menemukan hasil dari 2 variabel, yaitu:

1. Likes

2. Viewers

Dari kedua variable diatas kemudian dianalisa sehingga menemukan nilai rata-rata dari variable Likes dan Viewers. Untuk menghitung rata-rata dari variable likes dan Viewers yaitu dengan cara mengambil 10 postingan Kemudian dihitung sehingga menemukan nilai rata-rata dari masingmasing variable. Berikut merupakan tabel nilai rata-rata dari masing-masing Kosmetik terbaik di dunia: 
Tabel 1. Analisa Nilai Rata-Rata Nilai Variabel Likes to Viewers dari Akun Youtube Estee Lauder

\begin{tabular}{|c|c|c|}
\hline NO & LIKES & VIEWS \\
\hline 1 & 282 & 88,221 \\
\hline 2 & 107 & 13,521 \\
\hline 3 & 62 & 8,489 \\
\hline 4 & 47 & 253,345 \\
\hline 5 & 65 & 6,106 \\
\hline 6 & 24 & 2,251 \\
\hline 7 & 55 & 3,119 \\
\hline 8 & 1,003 & 106,482 \\
\hline 9 & 46 & 5,824 \\
\hline 10 & 526 & 41,086 \\
\hline total & 221.7 & 52,844 \\
\hline
\end{tabular}

Tabel 2. Analisa Nilai Rata-Rata Nilai Variabel Likes to Viewers dari Akun Youtube Revlon

\begin{tabular}{|c|c|c|}
\hline NO & LIKES & VIEWS \\
\hline 1 & 23 & 413 \\
\hline 2 & 19 & 538 \\
\hline 3 & 20 & 776 \\
\hline 4 & 21 & 573 \\
\hline 5 & 13 & 2,857 \\
\hline 6 & 18 & 618 \\
\hline 7 & 578 & 14 \\
\hline 8 & 456 & 20 \\
\hline 9 & 857 & 19 \\
\hline 10 & 462 & 10 \\
\hline total & 246.7 & 583.8 \\
\hline
\end{tabular}


Tabel 3. Analisa Nilai Rata-Rata Nilai Variabel Likes to Viewers dari Akun Youtube Maybelline New York

\begin{tabular}{|c|c|c|}
\hline NO & LIKES & VIEWS \\
\hline 1 & 419 & 15,542 \\
\hline 2 & 779 & 37,282 \\
\hline 3 & 817 & 54,319 \\
\hline 4 & 1600 & 120,582 \\
\hline 5 & 88,000 & 271,391 \\
\hline 6 & 625 & 45,502 \\
\hline 7 & 486 & 78,129 \\
\hline 8 & 269 & 40,783 \\
\hline 9 & 596 & 109,753 \\
\hline 10 & 142 & 2,666 \\
\hline total & 9373.3 & 77,595 \\
\hline
\end{tabular}

Tabel 4. Analisa Nilai Rata-Rata Nilai Variabel Likes to Viewers dari Akun Youtube MAC Cosmetics

\begin{tabular}{|c|c|c|}
\hline NO & LIKES & VIEWS \\
\hline 1 & 544 & 7,800 \\
\hline 2 & 253 & 5,700 \\
\hline 3 & 107 & 2,000 \\
\hline 4 & 245 & 4,800 \\
\hline 5 & 315 & 6,000 \\
\hline 7 & 115 & 3,200 \\
\hline 8 & 120 & 3,000 \\
\hline 9 & 179 & 3,400 \\
\hline 10 & 120 & 2,400 \\
\hline total & 222 & 4,256 \\
\hline
\end{tabular}


Tabel 5. Analisa Nilai Rata-Rata Nilai Variabel Likes to Viewers dari Akun Youtube Lancome

\begin{tabular}{|c|c|c|}
\hline NO & LIKES & VIEWS \\
\hline 1 & 28 & 2,500 \\
\hline 2 & 329 & 10,000 \\
\hline 3 & 138 & 3,600 \\
\hline 4 & 442 & 19,000 \\
\hline 5 & 11 & 2,100 \\
\hline 6 & 66 & 9,600 \\
\hline 7 & 295 & 37,000 \\
\hline 8 & 272 & 19,000 \\
\hline 9 & 268 & 775,000 \\
\hline 10 & 94 & 4,000 \\
\hline total & 194.3 & 88,180 \\
\hline
\end{tabular}

Setelah menghitung nilai rata-rata tersebut, maka akan mendapatkan hasil akhir nilai rata-rata dari variabel Likes to Views.

Tabel 6. Nilai Masing- Masing Variabel Pada Akun Youtube 5 Kosmetik Terbaik Didunia

\begin{tabular}{|c|c|c|c|c|c|}
\hline Variabel & $\begin{array}{c}\text { Estee } \\
\text { Lauder }\end{array}$ & Revlon & Maybelline & MAC & Lancome \\
\hline LIKES & 221.7 & 246.7 & 9373.3 & 222 & 194.3 \\
\hline VIEWERS & 52.844 & 583.8 & 77.595 & 4.256 & 88.180 \\
\hline
\end{tabular}

Sumber : Pengolah Data Excel

Pada akun Yoube terdapat 10 rasio yang relevan digunakan untuk mengukur kredibilitas pada masing-masing akun. Namun pada penelitian kali ini hanya berfokus untuk menghitung Likes to Video Viewers Ratio. Untuk menghitung kredibilitas dari masing-masing akun Youtube setiap Kosmetik terbaik di dunia, peneliti menghitung dengan cara: variabel 1 akan dibagi dengan variabel 2, sehingga ditemukan hasil Analisa dari rasio tersebut.

Tabel 7. Hasil Perhitungan Rasio Akun Youtube

\begin{tabular}{|c|l|c|c|c|c|c|}
\hline No & Ratio & $\begin{array}{c}\text { Estee } \\
\text { Lauder }\end{array}$ & Revlon & $\begin{array}{c}\text { Maybelline } \\
\text { New York }\end{array}$ & MAC & Lancome \\
\hline 1 & $\begin{array}{l}\text { Likes } \\
\text { To } \\
\text { Viewers }\end{array}$ & 0.004195367 & 0.422576225 & 0.120797732 & 0.052161654 & 0.002203447 \\
\hline
\end{tabular}

Sumber : Pengolah Data Excel 
Video Likes to Video Views memiliki karakteristik yang tinggi, artinya semakin tinggi nilai yang dihasilkan maka semakin baik kredibilitas dari performa akun tersebut. Untuk memberikan peringkat pada masing-masing Merek Kosmetik, peneliti memberikan angka 5 kepada yang mendapat nilai tertinggi dan angka 1 untuk merek Kosmetik yang mendapatkan nilai terendah. Berikut merupakan tabel urutan nilai yang dihasilkan oleh masing-masing merek Kosmetik.

Tabel 8. Nilai Rasio Akun Instagram 5 Merek Skincare Lokal Terbaik Tahun 2021

\begin{tabular}{|l|c|c|c|c|c|}
\hline \multirow{2}{*}{ RATIO } & \multicolumn{5}{|c|}{ NILAI } \\
\cline { 2 - 6 } & $\begin{array}{c}\text { Estee } \\
\text { Lauder }\end{array}$ & Revlon & $\begin{array}{c}\text { Maybelline } \\
\text { New York }\end{array}$ & MAC & Lancome \\
\hline $\begin{array}{l}\text { Video Likes } \\
\text { to Video } \\
\text { Views }\end{array}$ & 4 & 1 & 2 & 3 & 5 \\
\hline
\end{tabular}

Sumber : Pengolah Data Excel

Dari Tabel Nilai Rasio Akun Instagram 5 Kosmetik Terbaik di Dunia dapat disimpulkan bahwa Lancome mendapatkan nilai tertinggi untuk rasio Likes to Viewers. Sedangkan akun Instagram Revlon mendapatkan nilai terendah untuk rasio ini. Jadi, pada penelitian ini Revlon memiliki kredibilitas performa yang lebih baik dibandingkan dengan merek Kosmetik yang lainnya.

\section{KESIMPULAN}

Tujuan dari penelitian ini adalah mengetahui kredibilitas performa dari akun Youtube 5 Kosmetik Terbaik di Dunia menggunakan Likes to Viewers Ratio. 5 Kosmetik Terbaik di Dunia tersebut diantaranya: Estee Lauder, Revlon, Maybelline New York, MAC, dan Lancome Dari kelima merek Kosmetik tersebut dapat disimpulkan bahwa:

1. Peringkat pertama diraih oleh Revlon dengan nilai tertinggi yaitu 0.422576225

2. Peringkat kedua diraih oleh Maybelline New York dengan nilai 0.120797732

3. Peringkat ketiga diraih oleh MAC dengan nilai 0.052161654

4. Peringkat keempat diarih oleh Estee Lauder dengan nilai 0.004195367

5. Peringkat kelima diraih oleh Lancome dengan nilai terendah yaitu 0.002203447 


\section{DAFTAR PUSTAKA}

BPguide. (2018). Intip 10 Kosmetik Terbaik di Dunia Menurut Konsumen Dunis. In BpGuide.Id. https://bp-guide.id/AXkd75sW

Fachruddin, Sutiyana. Jaya, A. (2020). Perilaku Remaja dalam Penggunaan Media Sosial YouTube sebagai Media Baru 4.0. Komunikasi, Pembangunan, Dan Media, 18. https://uho.ac.id/prodi/pemerintahan/wp-content/uploads/sites/53/2020/02/PERILAKUREMAJA-DALAM-PENGGUNAAN-MEDIA-SOSIAL-YOUTUBE-SEBAGAI-MEDIAdikonversi.pdf

Hendika Permana, I. P. (2021). Analisis Rasio Pada Akun Youtube Untuk Penelitian Kualitatif Menggunakan Metode Ekploratif. In Jurnal Ilmiah Media Sisfo (Vol. 15, Issue 1, p. 40). https://doi.org/10.33998/mediasisfo.2021.15.1.970

Literate, S., \& Indonesia, J. I. (2020). View metadata, citation and similar papers at core.ac.uk. PENGARUH PENGGUNAAN PASTA LABU KUNING (Cucurbita Moschata) UNTUK SUBSTITUSI TEPUNG TERIGU DENGAN PENAMBAHAN TEPUNG ANGKAK DALAM PEMBUATAN MIE KERING, 274-282.

Maryam, I. and A. N. 2016). (2016). Pendekatan Eksploratif Untuk Meningkatkan Kemampuan Representasi Matematis Dan Kepercayaan Diri Siswa. In Jurnal Pena Ilmiah (Vol. 1, Issue 1, pp. 551-560). https://doi.org/10.23819/pi.v1i1.2984

Maulida, L. (2017). OKEZONE INNOVATION: Kisah YouTube yang Didirikan 3 Mantan Karyawan PayPal. In Techno.Okezone.Com. https://techno.okezone.com/read/2017/08/25/207/1763207/okezone-innovation-kisahyoutube-yang-didirikan-3-mantan-karyawan-paypal

Soelistyowati, R. D. (2018). Peran Youtube dalam Membangun Brand Image bagi Pengguna Aplikasi Gojek. DiMCC Conference Proceeding, 1(0), 165-176. http://ejournal.president.ac.id/presunivojs/index.php/DIMCC/article/view/515 